\title{
Exploring Elements of Effective E-learning Design for the Development of Student E-skills
}

\author{
Subashnie Soobramoney, Delene Heukelman \\ Durban University of Technology, Durban, South Africa
}

\begin{abstract}
The merits of E-learning technologies are undeniable consequently; E-learning has been widely adopted by universities across the world. This widespread adoption in South Africa coexists with well documented diversities in student levels of Eskills, caused by socio-economic challenges, causing undue pressure on students who do not have the required skills to harness the benefits of technology use for learning. Technology enhanced learning is invaluable, but careful consideration must be given to the design of technology enhanced learning tasks to prevent undue pressure on previously disadvantaged students. E-learning tasks may further be used as a tool to build student capacity to use E-learning to develop their E-skill and prepare them for a technology enhanced world. Qualitative data relating to E-skills development of sixteen undergraduate students enrolled in a blended E-learning classroom were recorded and possible relationships or effects that the use of E-learning had on students and their Eskill development were investigated. Straussiangrounded theory methods of analysis ensured thorough and consistent analysis of data. The underlying relationships and emerging theory suggest that task complexity, task duration and availability of ICT resources were important factors to be considered when selecting technology enhanced tasks. Carefully designed incrementally complex tasks coupled with the instructor's level of support were found to be crucial for students with lower levels of eskills to benefit from the learning task and develop their e-skills in the process. Selection of appropriate E-learning tools to balance the cognitive load, relating to both content and technology, assisted students in managing the task and developing their skill.
\end{abstract}

\section{Introduction}

Given the current technology dependent society, it may be easy to dismiss the notion that there may be individuals who are unable to use technology effectively however, mobile phone usage and a social media presence does not mean that an individual is ESkilled. E-skills describe one's ability to use ICT "within the context of a knowledge environment in order to participate creatively and innovatively in a world where ICT is an essential requirement for advancement in activities of government, civil society and business" [1][2]. Students are able to use their phones for social and entertainment purposes, but this does not necessarily mean that they can competently use technology for learning and innovation.

E-Inclusion refers to a community's ability to both contribute to and benefit from knowledge societies and the economy using ICT. As one moves away from urban areas towards rural areas, E-inclusion declines such that these communities remain disconnected from the digital world of information [3]. Since university entrance is not dependent on ICT related competencies, a typical cohort of first year student in a developing country like South Africa may be challenged with diversity in student E-skills. E-skills improve an individual's chance of finding work using a digital platform, work effectively using technology, use technology for self-development and improve their level of employment.

Learning optimized through the use of the internet, Learning Management Systems (LMSs) and related digital technologies, is called E-learning and has become increasingly popular due to innovations in these technologies that catalyzes teaching and learning [4]. Technology and the internet provide educators as well as students with flexibility, richness of materials, resource sharing, and access to large amounts of content and opportunities for interactive learning beyond the classroom. Understandably, universities across the world have adopted E-learning, making it difficult for students to escape technology enhanced learning. This paper aims to provide insight into how these valuable E-skills may be developed especially amongst students who have come from rural areas. This paper explores the use of E-learning by undergraduate students of diverse E-skills levels, in order to discover a possible connection between the design of E-learning tasks and the development of Eskills.

This paper describes the theoretical background of the concepts of E-skills and E-learning and moves on to examine literature that informs the design of $\mathrm{E}$ learning tasks in section 2, discussing specific competencies relating to E-skills as described in existing literature and presenting distinct levels in which E-skills may be categorized and achieved. Section 3 presents the selected methodology adopted 
to explore how E-learning tasks were designed to advance the E-skills of student users as a means to address the existing E-skills diversities of students within the same class. Section 4 presents an overview of the results discusses a framework that incorporates key factors needing consideration when selecting a technology enhanced task. The conclusion and recommendations are drawn in Section 5.

\section{Review of related literature}

\subsection{E-skills and E-Inclusion}

Due to the nature of ICT, namely its flexibility and benefits, most recent and current innovations involve digital technologies resulting in greater success for those countries and societies that are able to embrace the power of ICT to improve their position in any sector [5]. When individuals are prevented from developing their E-skills or benefitting from ICT due to circumstances beyond their control, a digital divide exists [3]. More especially the digital divide refers to the distance between those who are able to benefit from ICT and those who are prevented from doing so for various reasons [6].

E-inclusion and digital divide are contrasting phenomena. The "digital divide" originally referred to diversity in different communities' access to technology. As more and more efforts are being made to minimize the problem of access to ICT, the modern day digital divide includes diversities in skills such as E-skills or the capability of individuals to make effective use of technology [6].

Despite interventions towards providing access to ICT, especially in rural sectors of South Africa, the digital divide persists and unfair diversities widen the gap between E-inclusion and digital divide. Universities may not be able to solve the problem of access and integration of ICT to the public however; they can address the E-skills deficit of their students.

\subsection{E-Skills}

The era of connectivism resulting from the fourth industrial revolution requires individuals to be able to communicate using different media [7], collaborate effectively across cultural and institutional borders, combine sources and information to argue a point and contribute to online environments and knowledge societies through creative expression and selfpresentation [7].

E-skills refers to an array of technology related knowledge and skills ranging in complexity. [2] describes E-skills as a "collection of multi-levelled skills that require lower level skills to be developed prior to attempting the next set of skills". Describing specific competencies that must be acquired at each level, simplifies an instructor's task, allowing a better understanding of students' abilities at each level and the type of assistance they will need. Table 1 summarizes the distinct levels on which E-skills may be viewed as described by [2].

Table 1. E-skills Levels

\begin{tabular}{|l|l|l|}
\hline $\begin{array}{c}\text { E-skill } \\
\text { Level }\end{array}$ & \multicolumn{1}{|c|}{ Description } & \multicolumn{1}{|c|}{ ICT related Competencies } \\
\hline 1 & $\begin{array}{l}\text { Technology } \\
\text { Operation } \\
\text { Skills }\end{array}$ & Operate ICT unassisted \\
\hline 2 & $\begin{array}{l}\text { Fundamental } \\
\text { E-skills }\end{array}$ & $\begin{array}{l}\text { Use ICT to search for } \\
\text { information, evaluate/use } \\
\text { information to complete } \\
\text { basic tasks }\end{array}$ \\
\hline 3 & $\begin{array}{l}\text { Information } \\
\text { Analysis and } \\
\text { knowledge } \\
\text { Sharing } \\
\text { Skills }\end{array}$ & $\begin{array}{l}\text { Analyze information } \\
\text { Debate } \\
\text { Discuss } \\
\text { Present } \\
\text { creatively information }\end{array}$ \\
\hline 4 & $\begin{array}{l}\text { Strategic E- } \\
\text { skills }\end{array}$ & $\begin{array}{l}\text { Use of ICT for critical } \\
\text { thinking } \\
\text { Create knowledge } \\
\text { Use ICT innovatively and } \\
\text { creatively to solve } \\
\text { problems } \\
\text { Create new knowledge } \\
\text { and present strategically } \\
\text { in a knowledge society. }\end{array}$ \\
\hline
\end{tabular}

Technology Operation Skills require one to be able to use computing devices for basic functions without mush assistance [2][8][9]. Fundamental E-skills means that an individual is able to "use ICT to search for, evaluate and use information to effectively complete tasks related to work, study and everyday life". These lower level skills need to be "taught" therefore would benefit from formal instruction and regular practice [2][8][9].

An individual that has Information Analysis and knowledge Sharing Skills, would be able to not only search for information, but critically analyze the presentation and credibility of the information, compare with different sources, debate and discuss the application of this information using different digital platforms like e-mail, discussions, blogs, virtual conferences in order to improve their knowledge [8]. Strategic E-skills goes beyond understanding and applying and includes the use of ICT to support critical thinking, and the use of knowledge to creative new innovative solutions that may improve efficiency or understanding of a specific focus area and sharing this innovative contribution with a knowledge society [8][9].

Information Analysis and knowledge Sharing Skills and Strategic E-skills may be acquired through continued development in different contexts, group work and knowledge sharing amongst peers [10]. Strategic E-skills in particular are developed through 
experience, support and collaboration [11] whilst continuous usage of ICT supports the development of all levels of E-skills.

\subsection{E-learning}

Advancements in technology demand that individuals are sufficiently skilled to function in a knowledge society, teaching and learning pedagogies have moved away from content and teacher centered to learner-centered designs. Learner centered pedagogies place students at the center of the learning process, allowing students the flexibility to be creative, self-directed and motivated to construct knowledge [1]. This type of pedagogical design is intended to develop the type of skills that students need in a knowledge society, namely: life-long learning, independent learning, collaborative learning and E-skills [11].

Multiple approaches exist for technology enhanced classroom design. The exclusively online learning approach consists of students enrolled in an eclassroom, where the only means of contact between his peers and the teacher is through the E-classroom or through digital media such as email requiring students to use ICT for learning independently [12]. First year students, with diverse skills and socioeconomic backgrounds, require more assistance, training and contact time with a teacher than is offered by this learning approach, therefore a completely online approach is not ideal for first year students [12].

Blended learning is a pedagogical approach to learning in the digital age that combines face-to-face teaching and learning activities with technology enhanced teaching and learning activities. Blended learning provides more support to students than those pedagogies that are dependent on technology use to prepare for classroom discussions [13], or that are exclusively online. Blended learning is ideal for early development, because it provides greater flexibility and student-centeredness to address diversities in the student population [14]. Face-to-face and technology enhanced activities are selected and implemented in a way that supports each other, affording students the chance to become familiar with the coursework and technology in the classroom and supplement their learning with additional technology enhanced activities directed towards improving their learning and overcoming their challenges [9][15].

Successful E-learning means student success and student satisfaction, which leads to continued use of E-learning technologies. Continued use of technology is critical to achieving higher level E-skills [9]. The next section will discuss aspects of design that may contribute to a successful e-learning experience.

\subsection{E-learning designs}

The core function of E-learning is to use technology to improve the student learning experience across disciplines. With constant advances in technology and the available learning tools at his/her disposal can easily overwhelm instructors. Learning management Systems (LMS) provide instructors with an integrated environment in which the instructor can create a classroom and carry on with teaching and learning leaving the logistical aspects of software support, hardware requirements, safety of student and staff identity to support personnel[16]. Simply using an LMS as an extension to a traditional classroom to provide access to course content online does not capitalize on the benefits that technology has to offer. E-learning is not an LMS. The primary goal of any course is primarily to achieve the pedagogical goals therefore, the technology needed to enhance a task must be carefully selected for its fit to the learning task and pedagogical goals of the course.

LMS and the internet provides a selection of technologies to enhance learning like collaboration tools, discussion groups, wikis, videos, slides, simulations, online assessments, email, live chat etc. Incorporating too many tools into a course can cause a "technology overload" meaning that the course becomes overwhelming for a user, resulting in them avoiding many tasks altogether [17]. Selecting the right tool for the task involves many factors. In order to select a tool to enhance learning, consideration must be afforded to the cognitive level of learning associated with a task.

In order to build knowledge in a specific area regardless of discipline, the cognitive process begins with "low-level-learning", where one is trying to commit facts and concepts to memory, whilst gaining a basic understanding of a topic. Once this is achieved an individual is sufficiently equipped for higher levels of cognitive development through the evaluation of information and creation of knowledge and understanding [18]. [18] suggest that low order learning skills are important for conceptualizing information from resources and can be achieved through the use of slides, videos and simple quizzes. This low-level cognitive development relies on learning facts and understanding the concept. Midlevel cognitive development is achieved through active learning where a student is presented with a clearly defined task like a case study that requires the student to complete by sourcing and organizing information, then applying the factual information he/she has learned, to demonstrate competence. Higher order cognitive development requires the student to be able to collaborate with others in order to solve a complex problem. The cognitive development levels described by [18] bear similarities to the instructional methods for E-learning design proposed by [16] and are summarized in Table 2. [16] 
suggests that expositive methods are necessary for absorption of new information, application methods are suited to improve the student's understanding whilst collaborative methods make use of interpersonal skills needed to communicate one's ideas and share knowledge. Collaboration also allows students to share and debate their interpretations of the learning task and their application of this knowledge to real world problems.

Table 2. Summary of cognitive levels of learning and instructional methods of E-Learning

\begin{tabular}{|c|c|c|}
\hline $\begin{array}{c}\text { Cognitive } \\
\text { levels of } \\
\text { learning } \\
{[18]}\end{array}$ & $\begin{array}{c}\text { Instructional } \\
\text { methods for E- } \\
\text { learning } \\
{[16]}\end{array}$ & $\begin{array}{l}\text { E-learning tool to achieve } \\
\text { pedagogical goal }\end{array}$ \\
\hline Low-level & Expositive & $\begin{array}{l}\text { Presentation, videos, } \\
\text { demonstration }\end{array}$ \\
\hline Mid-level & Application & $\begin{array}{l}\text { Step-by-step task } \\
\text { completion, learning game, } \\
\text { Case-based scenarios, } \\
\text { asynchronous } \\
\text { communication (discussion } \\
\text { groups, blog, wiki) }\end{array}$ \\
\hline High level & Collaboration & $\begin{array}{l}\text { Synchronous } \\
\text { communication (Group } \\
\text { chats, wiki, blog, } \\
\text { discussion groups, video } \\
\text { conferences) }\end{array}$ \\
\hline
\end{tabular}

[18] maintains that short tasks that have clearly defined outcomes and require the use of easy-to-use technology is a more favored approach for users. [17] adds that perceived ease of use encourages students to continue using the technology but cautions instructors against the technology overload that results from too many or too complex technologically enhanced tasks. Technology overload is subjective depending on the student's E-skills level capability. A student new to technology enhanced learning is more inclined to experience overload due to the additional cognitive load that comes from having to also learn how to use the technology, whilst a student with higher E-skills may easily be able to complete more tasks in the same time. Once again, the student's E-skills plays a critical role in E-learning success.

The results of a quantitative study of university students conducted by [19] also posits that students experienced greater satisfaction in their blended learning courses as they progressed to the next year of study. Evidence was not conclusive that the second and third year courses were better structured and easier to use, therefore the students' experience could possibly have been influenced by their increasing familiarity with the LMS in each progressive year [17][20].

When technology is used to enhance a learning task, the total cognitive load on a student is a combination of the mental processing required to use the technology effectively, plus the mental processing power needed to complete the content specific learning task. Unlike computers, "mental processing powers of students cannot be upgraded" [17][21] therefore a complex learning task that requires the use of complex unfamiliar technology is likely to be avoided by a user. Adopting E-learning means that a student is required to learn subject content and the technology concurrently. An individual can only commit $100 \%$ of mental processing power to the technological and pedagogical learning task combined. To assign a complex learning task, an instructor would need to establish that the E-skill level of the student prevents an unmanageable cognitive load so that E-learning can be successful. Building Eskills at the early years of university would benefit the students in firstly improving their E-skills so that the technological cognitive load is decreased in progressive years, when the complexity of the content is likely to increase.

The aim of this research was to identify key aspects of students' experience with E-learning during their coursework that may be considered in designing Elearning tasks that are able to build E-skill capacity of students.

The remaining sections provide answers to the following research questions:

RQ1 How can E-learning tools be selected for a pedagogical learning task to improve E-skills?

RQ2 What aspects of E-learning design may stimulate the development of each E-skill level?

\section{Research Design}

The problem of not knowing how E-skills of students can be developed through E-learning lies in understanding diverse students' experiences with Elearning. Qualitative research allows for discovery of theories and constructs that are not well documented in order to develop a deeper understanding of a subject [12], as is the case with the relationship between Elearning and the development of E-skills.

Observing the normal experiences of first year students allow for the detection and development of E-skills from one level to the next to discover how students use E-learning, what keeps them using technology to learn and the relationship between Elearning technology usage and their E-skills development.

The research design used a case study of first year students enrolled in a four-year undergraduate ICT program at the Durban University of Technology in South Africa. A case study provides the benefit of studying a small number of cases in detail using appropriate methods to develop as full an understanding of that case as possible[12][22]. Participants in the case study were selected according to their E-skill level at the start of the course in order to monitor the development of students at diverse skill levels. Sixteen students, 3 females and 13 males participated voluntarily. Five participants were classified as experienced users due to their ability to 
comfortably use computers to at least operate the computer and use the computer for simple information processing. The remaining 11 were classified as novice users because these students had never used a computer prior to university. Some had not even used a smartphone. Participants were interviewed together with others who were on similar skill levels to encourage participation from participants as they listened to others in the same group that may have experienced similar challenges and development. Semi-structured interviewing techniques were adopted to collect data.

Grounded theory (GT) data analysis techniques involves the use of assigning codes to themes identified in qualitative data and thereafter comparing, contrasting and connecting related themes to discover new theories that can be traced easily back to the data [22]. Straussian Grounded Theory methods of qualitative data analysis is a strain of GT that provide researchers with guidelines to ensure a structured and thorough assessment, evaluation and analysis of through coding of themes, trends and relationships to arrive at emerging themes that contribute towards the research questions [12].

\section{Results}

Technology overload was detected in the responses of all novice participants like Mbu and Za's responses shown below. These students expressed anxiety due to their inability to complete mandatory tasks within the allocated times and secondly, their lack of experience with the selected technology.

Mbu: Miss $N$ tells us we must finish this free online course by this date and then another one by that date Za: But we don't even know how to register for the course. We are not sure how to do it. We don't know if we are doing it right. It is scary, we don't know if it will work and we have to do it ourselves.

Limited access to technology was also a cause for anxiety amongst both novice and experienced students, however more experienced students were able to find solutions to their challenges for example Timmy, Sli and Sphe had a higher level of E-skills before entering university:

Timmy: if you want to access YouTube what you gonna do, you don't have internet. Internet should go in hand with that devices.

Sli : Download, you can download videos from YouTube $\underline{\text { Sphe }}$ : Yea, you can download on campus and take it home.

Mandatory tasks allocated by the instructor had to be completed within a timeframe. Students that were unable to use the technology often did not complete it or, depending on the mark allocation opted to complete tasks that had a greater weighting on their final grade. Novice students, in particular, were heavily dependent on their instructor and more experienced peers to show them how to use the designated technology required for the learning task. The high cognitive load experienced by the student as a result of frequent technology dependent tasks was evident in student responses as they stated that there was too much to learn for them to manage their work.

Interviews conducted three months and then six months later showed that students' attitude towards Elearning tools had improved. Students acknowledged that the early stages of the course were challenging however they found their lecturers responsiveness to their difficulties helped them cope with using the technology and completing the learning task itself. Students commented that they regularly consulted their lecturer at the early stages of E-learning adoption to request help in using the tool. The usually lecturer responded with demonstration at first and then later with directions to online resources like Khan academy to help them learn how to use different tools or learn new concepts.

Students were happy to use new E-learning tools if their lecturer thought it would be useful. They experienced pride in their new ability which motivated them to continue using the online learning environment outside of contact lectures. Student reflected that in hindsight they were able to appreciate how the learning tool was instrumental in adding to their knowledge of a particular concept that they might have been studying. Q stated that he enjoyed looking for more information from E-books stating that the additional reading helped him learn more.

$\mathrm{Za}$ and $\mathrm{Mbu}$, who were both novice users added that the discussion groups were especially useful to practice typing in the early stages but $\mathrm{Za}$ found that it was a useful platform for her to voice her thoughts and questions because she was normally shy.

Both novice and experienced users agreed that their greatest challenges in the early adoption phases was the speed at which they were able to complete a task, their access to technology to complete the learning task as well as their ability to manage the many learning tasks across multiple courses they were taking in that semester. Notwithstanding they did maintain that the tasks they were required to complete was useful for their learning and finding information and instrumental in helping them get familiar with the "computer".

\section{Discussion}

Striking a balance between student capability, learning task, cognitive level of task, number of tasks and the available support from instructors and peers is necessary to improve the student's learning experience. Cognitive loading is a critical point of interest when designing an activity or course [21]. Appropriate instructor support enables the student to complete the technology enhanced task because the instructor helps to relieve some of the technological cognitive burden on the student making the learning experience more manageable [2]. E-learning task design however, must take note of the duration and 
frequency of tasks to ensure that the task stimulates learning and does not overwhelm the student. A student that is new to technology usage and still in the process of developing lower level E-skills will require more time for each learning task therefore is able to complete fewer learning tasks. To prevent students from omitting learning activities that are essential for the learning outcome, the instructor may communicate its importance and limit learning tasks to only those that are absolutely necessary for achieving pedagogical goals. Students' access to technology further affect the complexity, duration and frequency of task since students with access only on campus will have limited time to complete each learning task.

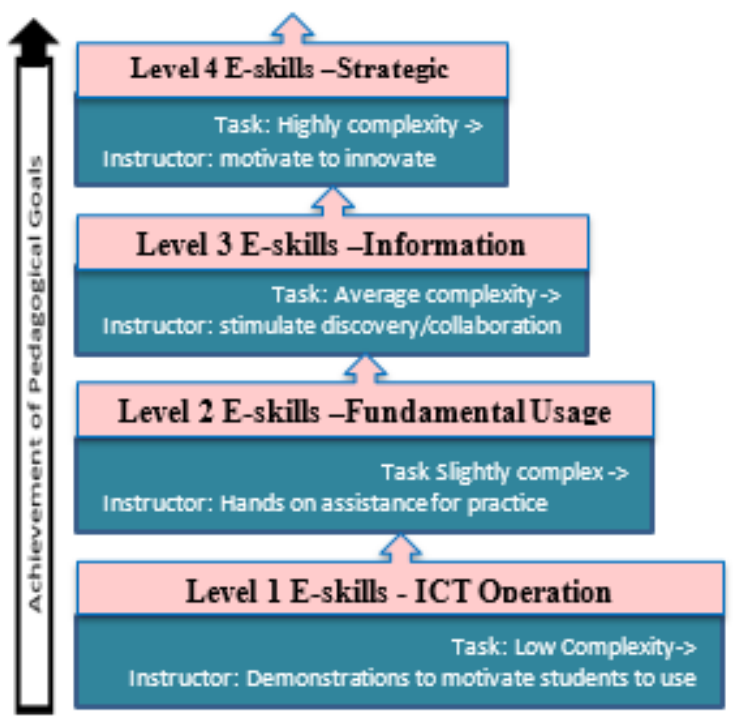

Figure 1. Sustained incremental development of E-skills through E-learning tasks design

The type of support required as students progressed from one E-skill level to the next was significantly different. Early stages of E-skill development required a lesson on the technology itself and a "show and tell" interaction with the student. As each E-skill level was achieved students showed evidence of greater independence when working with technology. Experienced users found solutions to challenges and were stimulated to complete tasks that required the use of unfamiliar technology if their lecturer thought it would be useful to their learning [23]. Figure 1 depicts the gradual increase in task complexity coupled with appropriate support to stimulate the development of each level of E-skills onto the next level. Achievement of pedagogical goals remain as the primary goal of course design [23]. As a student achieves each level of E-skills competence, the instructor may slowly introduce activities than stimulate the student to develop the next level of E-skills. Since the pedagogical goals are at the focal point of the learning task, the type of stimulation required depended on the cognitive level at which the pedagogical concept is being developed and the student's current level of Eskills.

\section{Conclusion and Recommendations}

Achieving course outcomes remains the instructor's priority however; improved E-skill levels may be achieved as a subsidiary goal to the achievement of course outcomes. Sustained incremental complexity theorizes that subjecting a student to incrementally complex technology dependent tasks, together with instructor support relative to the students' current E-skill level, may result in E-skills development to the next level of Eskills. Incremental complexity nudges students towards learning to use new technologies in useful ways. Sustaining this increasing complexity by providing the appropriate instructor support for each level, guides students towards developing the next Eskill level. Instructor support further ensures that students are not demotivated and subsequently abandon the task altogether, thus missing the learning opportunity. As students become more confident about their ability to use technology effectively, their dependence on the instructor decreases such that they are able to experiment and explore new technologies required to complete their tasks without becoming overwhelmed.

Designing an E-classroom or individual technology enhanced learning activities need to balance these factors to maximize the students technological and pedagogical cognitive development. Table 3 shows the three levels of cognitive development that an individual will experience when they are required to build knowledge in any specific area [16][18] each requiring various levels of cognitive stimulation [21]. Table 3 provides a guideline for E-learning design that combines the phases of cognitive development of a concept and its required method of instruction for development, with the E-skills level of the student who will be experiencing this cognitive development. Acknowledging the relationship between E-skills level of a student (technological cognitive load) and the cognitive level of development to be achieved by a learning task may help reduce and possibly prevent technology overload [21]. Table 3 incorporates incremental complexity suggesting E-skill development goals that can be achieved at each phase of cognitive development to stimulate E-skill development using appropriate E-learning tools.

It is recommended that the conceptual relationships represented on Table 3 be tested using quantitative methods. 
Table 3. Levels of cognitive development

\begin{tabular}{|c|c|c|c|c|}
\hline $\begin{array}{c}\text { Cognitive Level } \\
\text { Development of } \\
\text { Pedagogical } \\
\text { Concept } \\
\text { [18] } \\
\end{array}$ & $\begin{array}{c}\text { Cognitive } \\
\text { Stimulation } \\
\text { Required } \\
{[21]}\end{array}$ & $\begin{array}{c}\text { Current } \\
\text { E-skill } \\
\text { Level } \\
{[2]}\end{array}$ & $\begin{array}{c}\text { E-skill } \\
\text { Development } \\
\text { Goal } \\
{[2][23]}\end{array}$ & $\begin{array}{r}\text { E-L Type } \\
\text { Activity } \\
{[16][17][18]}\end{array}$ \\
\hline \multirow{2}{*}{ Low } & \multirow{2}{*}{ Instruction of content } & $\mathrm{L} 1$ & $\begin{array}{l}\text { E-content } \\
\text { engagement }\end{array}$ & $\begin{array}{l}\text { In class } \\
\text { Presentation }\end{array}$ \\
\hline & & L2 & $\begin{array}{l}\text { Online content } \\
\text { engagement }\end{array}$ & $\begin{array}{l}\text { Presentation, E- } \\
\text { book }\end{array}$ \\
\hline \multirow{3}{*}{ Medium } & \multirow{3}{*}{$\begin{array}{l}\text { Application of facts } \\
\text { acquired }\end{array}$} & $\mathrm{L} 2$ & $\begin{array}{l}\text { Produce digital } \\
\text { document }\end{array}$ & $\begin{array}{l}\text { report, chart, } \\
\text { blog response }\end{array}$ \\
\hline & & L3 & $\begin{array}{l}\text { engage in } \\
\text { interactive digital } \\
\text { activities }\end{array}$ & $\begin{array}{l}\text { Search for and } \\
\text { present } \\
\text { information } \\
\text { simulation, } \\
\text { games }\end{array}$ \\
\hline & & L4 & $\begin{array}{l}\text { Analysis of } \\
\text { current } \\
\text { applications of } \\
\text { concept }\end{array}$ & $\begin{array}{l}\text { Discussion } \\
\text { group }\end{array}$ \\
\hline \multirow{3}{*}{ High } & \multirow{3}{*}{$\begin{array}{l}\text { Discussion of Content } \\
\text { and application }\end{array}$} & $\mathrm{L} 2$ & $\begin{array}{l}\text { Brief contribution } \\
\text { to online } \\
\text { discussion }\end{array}$ & $\begin{array}{l}\text { Reflections of } \\
\text { concept on } \\
\text { blog/discussion, } \\
\text { group thread }\end{array}$ \\
\hline & & L3 & $\begin{array}{l}\text { Communicate } \\
\text { interpretations of } \\
\text { information, } \\
\text { provide validated } \\
\text { arguments }\end{array}$ & $\begin{array}{l}\text { Threads to } \\
\text { stimulate } \\
\text { independent } \\
\text { content research } \\
\text { and } \\
\text { application(focus } \\
\text { group } \\
\text { discussion) }\end{array}$ \\
\hline & & L4 & $\begin{array}{l}\text { Initiate } \\
\text { Discussion } \\
\text { groups for } \\
\text { innovative } \\
\text { Application of } \\
\text { Concept } \\
\end{array}$ & $\begin{array}{l}\text { forums, chats, } \\
\text { discussion } \\
\text { group, video- } \\
\text { conferencing } \\
\text { (self-initiated } \\
\text { discussions) } \\
\end{array}$ \\
\hline
\end{tabular}

\section{References}

[1] H. Duisterwinkel, H. van der Aalst, and P. den Brok, "Towards a learning-centered design framework for blended Learning," in The Open and Flexible Higher Education Conference 2014, AGH University of Science and Technology, Krakow, 2014, pp. 120-141.

[2] S. Soobramoney and D. Heukelman, "The Four Is of E-skills," in 2019 Conference on Information and Communications Technology and Society(ICTAS), Durban, South Africa, 2019.

[3] R. Fasasi and D. Heukelman, "ICT: performance evaluation of community development worker's in South Africa on e-skills," Information Technology for Development, pp. 1-15, 2017.
[4] W. Bhuasiri, O. Xaymoungkhoun, H. Zo, J. J. Rho, and A. P. Ciganek, "Critical success factors for e-learning in developing countries: a comparative analysis between ICT experts and faculty," Computers \& Education, vol. 58, no. 2, pp. 843-855, 2012.

[5] S. Baller, S. Dutta, and B. Lanvin, "The global information technology report 2016," in World Economic Forum, Geneva, 2016, pp. 1-307.

[6] E. Bornman, "Information society and digital divide in South Africa: results of longitudinal surveys," Information, Communication \& Society, vol. 19, no. 2, pp. 264-278, 2016.

[7] S. C. Ukwoma, N. E. Iwundu, I. E. Iwundu, D. Baker, and D. Baker, "Digital literacy skills possessed by students of UNN, implications for effective learning and performance: a study of the 
MTN Universities Connect Library," New Library World, vol. 117 , no. 11/12, pp. 702-720, 2016.

[8] A. Scheerder, A. van Deursen, and J. van Dijk, "Determinants of Internet skills, uses and outcomes. a systematic review of the second-and third-level digital divide," Telematics and Informatics, vol. 34, no. 2017, pp. 1607-1624, 2017.

[9] A. B. Youssef, M. Dahmani, and N. Omrani, "Information technologies, students'e-skills and diversity of learning process," Education and Information Technologies, vol. 20, no. 1, pp. 141$159,2015$.

[10] K. Krauss, C. Simuja, and S. Conger, "ICT education practices in marginalized rural schools in South Africa: considerations for adequate sensemaking and practical immersion," in Proceedings of SIG GlobDev Eighth Annual Workshop, Fort Worth, Texas, USA, 2015.

[11] B. Gros and F. J. García-Peñalvo, "Future trends in the design strategies and technological affordances of e-learning," Learning, Design, and Technology: An International Compendium of Theory, Research, Practice, and Policy, pp. 1-23, 2016.

[12] W. Feeler, "Being there: A grounded-theory study of student perceptions of instructor presence in online classes," Ph.D, The Graduate College at the University of Nebraska, The University of Nebraska-Lincoln, Lincoln, Nebraska, 2012.

[13] P. Wastiau, R. Blamire, C. Kearney, V. Quittre, E. Van de Gaer, and C. Monseur, "The use of ICT in education: a survey of schools in Europe," European Journal of Education, vol. 48, no. 1, pp. 11-27, 2013.

[14] S. A. Becker, M. Cummins, A. Davis, A. Freeman, C. G. Hall, and V. Ananthanarayanan, "NMC horizon report: 2017 higher education edition," The New Media Consortium, Austin, Texas2017.

[15] N. T. T. Thai, B. De Wever, and M. Valcke, "The impact of a flipped classroom design on learning performance in higher education: looking for the best "blend" of lectures and guiding questions with feedback," Computers \& Education, vol. 107, pp. 113-126, 2017.

[16] B. Ghirardini, E-learning methodologies: A guide for designing and developing e-learning courses. Food and Agriculture Organization of the United Nations, 2011.

[17] N. Zanjani, "The important elements of LMS design that affect user engagement with elearning tools within LMSs in the higher education sector," Australasian Journal of Educational Technology, vol. 33, no. 1, 2017.

[18] K. H. Lau, T. Lam, B. H. Kam, M. Nkhoma, J. Richardson, and S. Thomas, "The role of textbook learning resources in e-learning: A taxonomic study," Computers \& Education, vol. 118, pp. 1024, 2018.

[19] A. Aristovnik, N. Tomazevic, D. Kerzic, and L. Umek, "The impact of demographic factors on selected aspects of e-learning in higher education," The International Journal of Information and Learning Technology, vol. 34, no. 2, pp. 114-121, 2017.

[20] R. Yilmaz, "Exploring the role of e-learning readiness on student satisfaction and motivation in flipped classroom," Computers in Human Behavior, vol. 70, pp. 251-260, 2017.

[21] K. Whitenton. (2013). Minimize Cognitive Load to Maximize Usability. Available: https://www.nngroup.com/articles/minimizecognitive-load/

[22] J. W. Creswell, Research design: qualitative, quantitative, and mixed methods approaches, 4th ed. (no. Book, Whole). Thousand Oaks: SAGE Publications, 2014.

[23] S. Soobramoney and D. Heukelman, "Exploring Sustained Incremental Development of E-skills through Effective E-learning Design," in 2019 Canadian International Conference on Education, Toronto, Canada, 2019. 